\title{
イオン濃度を変数とした連立方程式の解による 混合物中の弱酸または陽イオンの滴定定量
}

(1977 年 7 月 13 日受理)

石川 德久・松下寛*

㫮位差滴定の結果を用いて弱酸または陽イオン混合物の組成を決定するために, 正確な物質収支およ び電荷収支関係に基つくく線型連立方程式を提示した。

操作はつぎのようである。イオン選択性電極を用い,一定イオン強度下で，混合物成分の基準溶液 (既知滣度)および陚料混合物沉ついての滴定曲線を求める。混合物およびその成分の滴定曲線上で，そ れぞれ一定イオン濃度（すなわち，一定電極電位）に達するK要する滴定郕の体積を読みとる。このと き，測定イオン濃度および滴定剂の体積を变数とした尰立方程式を解くことにより，混合物の組成を決 定することができる。

本法は，定量計算に平衡定数の値を必要としない利点を有する。

\section{1 㒂 曹}

既報》で，著者らは定奄位滴定を利用し，普通の容量分析法で は分析不可能な任意の酸または陽イオン泟合物の分别定置を行な ろ新しい方法について報告した。この方法は，部算上，平衡定数 の值を必要としない利点があるが，他方多数の検量線を作䧶する 必要があった。

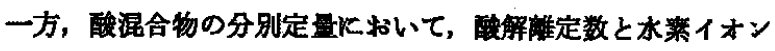
濃度が既知のとき火は, $\mathrm{pH}$ 滴定曲線の久を用いて解析的方法て 分別定量することができ2)，検量線が不要で実験操作は簡単に なる。しかし，泖度に基つく平衡定数の值はイオン強度によって 異なるため, 平氛定数の值が必要な従来の方法では，実検をその 值が求められたイオン強度に限定するか, るしくは使用するイオ ン強度での平衡定数をあらかじめ正確に求めなけれは去ならないと いら不便がある。

そこで，從来の方法と既報”の方法の不便な点を補う方法，す なわら平衡定数の倠を必要とせず，しかす多数の検量線を用いな いですを方法があれば便租である。本竍では，酸・塩基滴定を利

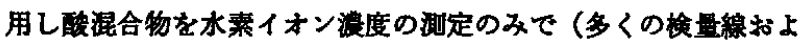
び平衙定数の筗を用いないで）分別定量する方法を提示し，この

\footnotetext{
* 中部工莱大学工莱化学科，487 春日井市松本町

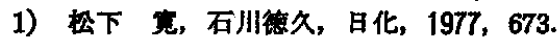

2）油井敬夫, 㪯藤正三郎, 日化, 76，1266(1955).

3) N. Purdie, M. B. Tomson, G.K. Cook, Anal. Chem., 44. 1525 (1972).

4) J. J. Kankare, ibid., 45, 1877(1973).

5) F. Ingman, A. Johansson, S. Johansson, R. Karlsson, Anal. Chim. Acta, 64, 113(1973).

6) A. Ivaska, Talanta, 21, 1167, 1175(1974); 22, 995 (1975).

7) C. McCallum, D. Midgley, Anal.Chim. Acta, 78, 171 (1975).

8) C. Mc Callum, D. Midgley, Anal.Chem., 48, 1232(1976).
}

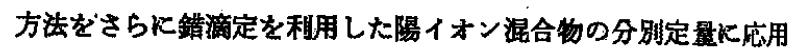
した結果について報告する。

\section{2 理論亡增作}

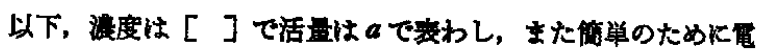
荷は省略する。さらに, 溶液のイオン強度をすべて一定とし,こ れによってイオン活量係数を一定にする。

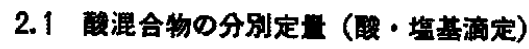

体稜 $V$, 漫度 $c_{\mathrm{m}}$ の $i_{\mathrm{m}}$ 塩基酸 $H_{i_{\mathrm{m}}} A^{m}$ の湿合物溶液 $(m=1$,

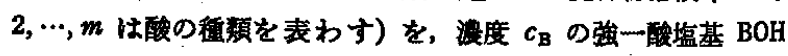
液で滴定し，滴定量をvとする。一般飞，酸 $\mathrm{H}_{\mathbf{i m}_{\mathrm{m}}} \mathrm{A}^{m}$ の全混成解 教定数を $\beta_{m j}$ とすれば,

$$
\begin{gathered}
\mathrm{H}_{i_{\mathrm{m}}} \mathrm{A}^{m} \rightleftharpoons j \cdot \mathrm{H}+\mathrm{H}_{\ell_{m}-j} \mathrm{~A}^{m} ; \quad \beta_{m j}=\frac{a_{\mathrm{H}} \cdot\left[\mathrm{H}_{i_{m}-j} \mathrm{~A}^{m}\right]}{\left[\mathrm{H}_{i_{m}} \mathrm{~A}^{m}\right]} \\
m=1,2, \cdots, m ; j=1,2, \cdots, i_{m}
\end{gathered}
$$

全滴定曲線は，既報1)の（7）式を整理することにより(既報で は湿度解離定数を用いているが)，次式で表わされるす。

$$
\begin{aligned}
c_{\mathrm{B}} v+(V+v) \cdot\{[\mathrm{H}]-[\mathrm{OH}]\} \\
=\sum_{m=1}^{m} \frac{\sum_{j=1}^{t_{m}} j \cdot \beta_{m j} \cdot a_{\mathrm{H}}^{-j}}{1+\sum_{j=1}^{t_{m}} \beta_{m j} \cdot a_{\mathrm{H}}^{-j}} \cdot c_{\mathrm{m}} V
\end{aligned}
$$

つぎに，体䖽 $V$ ，既知漠度 $c_{\mathrm{m}}^{r}$ の純 $\mathrm{H}_{i_{\mathrm{m}}} \mathrm{A}^{m}$ 基準液について

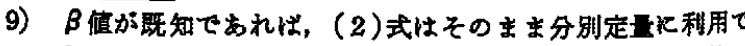
きる.すなから（2）式仕各 $\mathrm{pH}$ 檤したがって各 $a_{\mathrm{H}}$ 值K つw $\tau, c_{\mathrm{m}}(m=1,2, \cdots, m)$ k関子る線型連立方程式火な

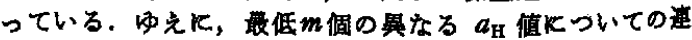
立方程式を解けは， $c_{\mathrm{m}}(m=1,2, \cdots, m)$ を決定することか

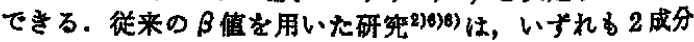

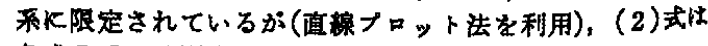
多成分系の分别定量に対する一般式化相当する。 
の滴定曲線を求めれ代（滴定量を $v_{\mathrm{m}}$ とする），(2)式から

$c_{\mathrm{B}} v_{\mathrm{m}}+\left(V+v_{\mathrm{m}}\right) \cdot\{[\mathrm{H}]-[\mathrm{OH}]\}$

$$
=\left\{\frac{\sum_{j=1}^{i_{m}} j \cdot \beta_{m j} \cdot \alpha_{\mathbf{H}}^{-j}}{1+\sum_{j=1}^{i_{m}} \beta_{m j} \cdot \alpha_{\mathrm{H}}^{-j}}\right\} \cdot c_{m}^{\gamma} V, m=1,2, \cdots, m
$$

が成立する。ここで、つぎのような定㻎操作を行なう。陚料液お゙ よび基準液の滴定曲線飞おいて, 同し $\mathrm{pH}$ 值における滴定量 $v$, $v_{\mathrm{m}}(m=1,2, \cdots, m)$ を求める。このとき，(2)，(3)式中の $a_{\mathrm{H}}$ 值 柱同じ值となる。したがって，(3)式右辺の $\beta_{m}$ ，を含む大カッ シの項を(2)式の右辺代入すれば，

$$
\begin{aligned}
& c_{\mathrm{B}} v+(V+v) \cdot\{[\mathrm{H}]-[\mathrm{OH}]] \\
& =\sum_{m=1}^{m}\left\{c_{\mathrm{B}} v_{\mathrm{m}}+\left(V+\bar{v}_{\mathrm{m}}\right) \cdot([\mathrm{H}]-[\mathrm{OH}])\right\} \cdot \frac{c_{\mathrm{m}}}{c_{\mathrm{m}}^{\tau}}
\end{aligned}
$$

となる。ゆえに，最低的個の異なる $\mathrm{pH}$ 值炕おける滴定量を求め れば, (4) 式の $c_{m}(m=1,2, \cdots, m)$ に閶子る線型連立方程式を 解くことKより，各酸の灌度を決定することができる。

とくに，2成分系 $(m=1,2)$ のときK恃，(4)式加

$$
y=\frac{c_{1}}{c_{1}^{r}}+\frac{c_{2}}{c_{2}^{r}} \cdot x
$$

ここで,

$$
\begin{aligned}
& x=\frac{c_{\mathrm{B}} v_{2}+\left(V+v_{2}\right) \cdot\{[\mathrm{H}]-[\mathrm{OH}]\}}{c_{\mathrm{B}} v_{1}+\left(V+v_{1}\right) \cdot\{[\mathrm{H}]-[\mathrm{OH}]\}} \\
& y=\frac{c_{\mathrm{B}} v+(V+v) \cdot\{[\mathrm{H}]-[\mathrm{OH}]\}}{c_{\mathrm{B}} v_{1}+\left(V+v_{3}\right) \cdot\{[\mathrm{H}]-[\mathrm{OH}]\}}
\end{aligned}
$$

したがって, $y$ 対 $x$ の直線ブロットの勾配と切点からそれぞれ $c_{2}, c_{1}$ が求められる。

\section{2 灀イオン混合物の分別定量 (錯滴官)}

体稓 $V$, 濃度 $c_{m}$ の陽イオン $\mathrm{M}^{m}$ の混合液 $(m=1,2, \cdots, m$ は

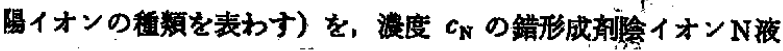
で滴定し，滴定量をりとする（Nイオン選択性電極を用いるむの とする)。

生成した錯体 $\mathrm{M}^{m} \mathrm{~N}_{n}$ の安定度定数む゙よび条件安定度定数をそ れぞれ $\beta_{m n}, \beta_{m n}^{\prime}$ で表わせば，一般に

$$
\begin{aligned}
& \mathrm{M}^{m}+n \cdot \mathrm{N} \Longleftrightarrow \mathrm{M}^{m} \mathrm{~N}_{n}, \\
& \beta_{m n}^{\prime}=\frac{\left[\mathrm{M}^{m} \mathrm{~N}_{n}\right]}{\left[\mathrm{M}^{m /}\right] \cdot\left[\mathrm{N}^{\prime}\right]^{n}}=\frac{\beta_{m n}}{\alpha_{M^{m} \cdot \alpha_{N}^{n}}} \\
& \quad m=1,2, \cdots, m ; n=1,2, \cdots, n_{m}
\end{aligned}
$$

ここで, $\left[\mathrm{M}^{m !}\right]$ は錯体 $\mathrm{M}^{m} \mathrm{~N}_{n}\left(n=1,2, \cdots, n_{\mathrm{m}}\right)$ 以外の $\mathrm{M}^{m}$ を 含むすへてての種の総澧度を，また $[\mathrm{N} !]$ は錯体 $\mathrm{M}^{m} \mathrm{~N}_{n}(m=1,2, \cdots$ $\left.m ; n=1,2, \cdots, n_{m}\right)$ 以外のNを含むすべての種の総丧度を表わ す。また， $\alpha_{\mathrm{Mm}}, \alpha_{\mathrm{N}}$ はそれぞれ $\mathrm{M}^{m}, \mathrm{~N}$ の副反応保数である (多 核錯体は無視でさるすのとする)。

全谪定曲線は，既報1)の(21) 式を整理することにより，次式で 表わされる10)。

$$
c_{\mathrm{N}} v-(V+v) \cdot\left[\mathrm{N}^{\prime}\right]=\sum_{m=1}^{m} \frac{\sum_{n=1}^{n_{m}} n \cdot \beta_{m n}^{\prime} \cdot\left[\mathrm{N}^{\prime}\right]^{n}}{1+\sum_{n=1}^{n_{m}} \beta_{m n}^{\prime} \cdot\left[\mathrm{N}^{\prime}\right]^{n}} \cdot c_{m} V
$$

10)（9)式は $c_{\mathrm{m}}(m=1,2, \cdots, m)$ k网して線型連立方程式の 形になっている.したがって，脚注 9)で述へたように， $\boldsymbol{\beta}_{m n}^{\prime}$ 值が既知であればNイオン選択性電婳を用い最低 $m$ 個の異なる [N']值を測定することにより，分䐓定量する ことができる。

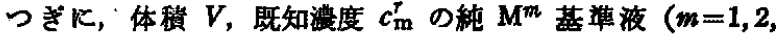
$\cdots, m)$ 㶤ついての滴定曲線を求めれば（滴定量を $\boldsymbol{v}_{\mathrm{m}}$ とする）, (9) 式から,

$$
\begin{gathered}
c_{\mathrm{N}} v_{m}-\left(V+v_{m}\right) \cdot\left[\mathrm{N}^{\prime}\right] \\
=\left\{\frac{\sum_{n=1}^{n_{m}} n \cdot \beta_{m n}^{\prime} \cdot\left[\mathrm{N}^{\prime}\right]^{n}}{1+\sum_{n=1}^{n_{m}} \beta_{m n}^{\prime}\left[\mathrm{N}^{\prime}\right]^{n}}\right] \cdot c_{m}^{r} V \\
m=1,2, \cdots, m
\end{gathered}
$$

ここで，試料液と基準液の滴定曲線において，同じ電位值すな

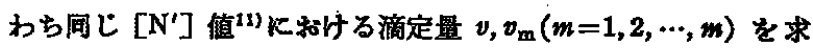
める。このとき，(9)，(10)式中の [N']值恫じになるため, (10) 式右辺の $\beta_{m n}^{\prime}$ 点む大カ⿻ ることにより,

$$
c_{\mathrm{N}} v-(V+v) \cdot\left[\mathrm{N}^{\prime}\right]=\sum_{m=1}^{m}\left\{c_{\mathrm{N}} v_{\mathrm{m}}-\left(V+v_{\mathrm{m}}\right) \cdot\left[\mathrm{N}^{\prime}\right]\right\} \cdot \frac{c_{m}}{c_{\mathrm{m}}^{i}}
$$

が得られる。ゆえに：（4）式の捗合之同棣飞して，(11）式の $c_{\mathrm{m}}$ 火関する線型連立方程式を解くことにより， $c_{m}(m=1,2, \cdots, m)$ が求められる。

とくK，2成分系のときKは $(m=1,2) ，(11)$ 式加ら (5) 式と 同じ形の式が得られる。ただし（5)式で，

$$
\begin{aligned}
& x=\frac{c_{\mathrm{N}} v_{2}-\left(V+v_{2}\right) \cdot\left[\mathrm{N}^{\prime}\right]}{c_{\mathrm{N}} v_{1}-\left(V+v_{1}\right) \cdot\left[\mathrm{N}^{\prime}\right]} \\
& y=\frac{c_{\mathrm{N}} v-(V+v) \cdot\left[\mathrm{N}^{\prime}\right]}{c_{\mathrm{N}} v_{1}-\left(V+v_{1}\right) \cdot\left[\mathrm{N}^{\prime}\right]}
\end{aligned}
$$

である。ゆきに（5）式の直線ブロットから $c_{1}, c_{2}$ が決定され 万。

なお，定量基本式である（4)，(11) 式の算出過程においてはな んら近似関係を用いていないため，(4)，(11) 式は一般的に成立 するるのである。

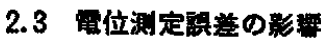

本法は電位着滴定曲線を利用するため，電位（または一定イ才

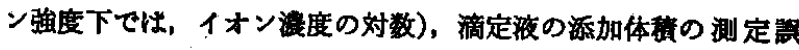
差は試料液および基準液の滴定曲線に直接影䇾し, ひいてはこれ

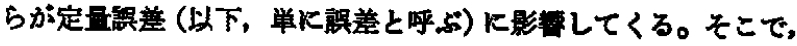
ここては酸混合物の分别定量を例にとり，数值計算から $\mathrm{pH}$ 湘定

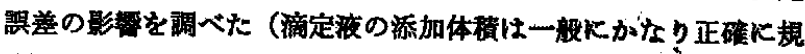

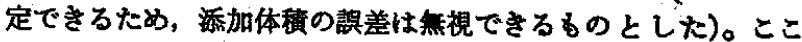
で, 試料仕 $p \beta=3$ の酸 1 と $p \beta=5$ の酸 2 の混合物; 試料体程 は $100 \mathrm{ml}$ ，滴定液は $0.1 \mathrm{~mol} / l \mathrm{KOH}$ とし，また酸 1 および酸 2

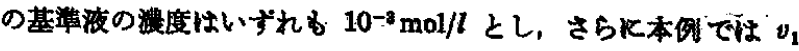
$=0.9 \sim 1.0 \mathrm{ml}, v_{2}=0.2 \sim 0.8 \mathrm{ml}$ の篧囲にあるので; 添加体磧 は $0.001 \mathrm{ml}$ まで測定できるすのとした。

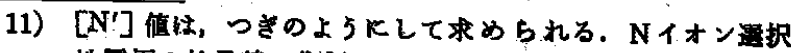

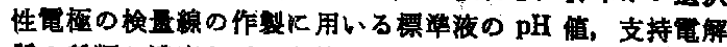
算の稙類と濃度などの条件をすべて試料湤のそれと同じに

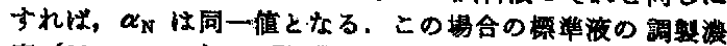
度（Nイオンの）は[N']値飞相当するため，電位対調慗

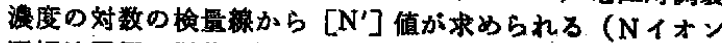
遙択性電轸の䉓位は，イオン強度一定の㧹合，[N]值の関 数となるが， $\alpha_{\mathrm{N}}$ が一定であるがり電位は見かけ上 $\left[N^{\prime}\right]$ $\left(=\alpha_{\mathrm{N}} \cdot[\mathrm{N}]\right) \cdot$ の成数となる) 
Table 1 Percent analytical errors resulting from systematic errors in $\mathrm{pH}$ values on titration plots for titrations of acid-1 $(p \beta=3)+\operatorname{acid}-2(p \beta=5)$ with $0.1 \mathrm{~mol} / l \mathrm{KOH}^{a}$

(1) $10^{-3} \mathrm{~mol} / \mathrm{l}$ acid-1 $+10^{-8} \mathrm{~mol} / \mathrm{l}$ acid-2

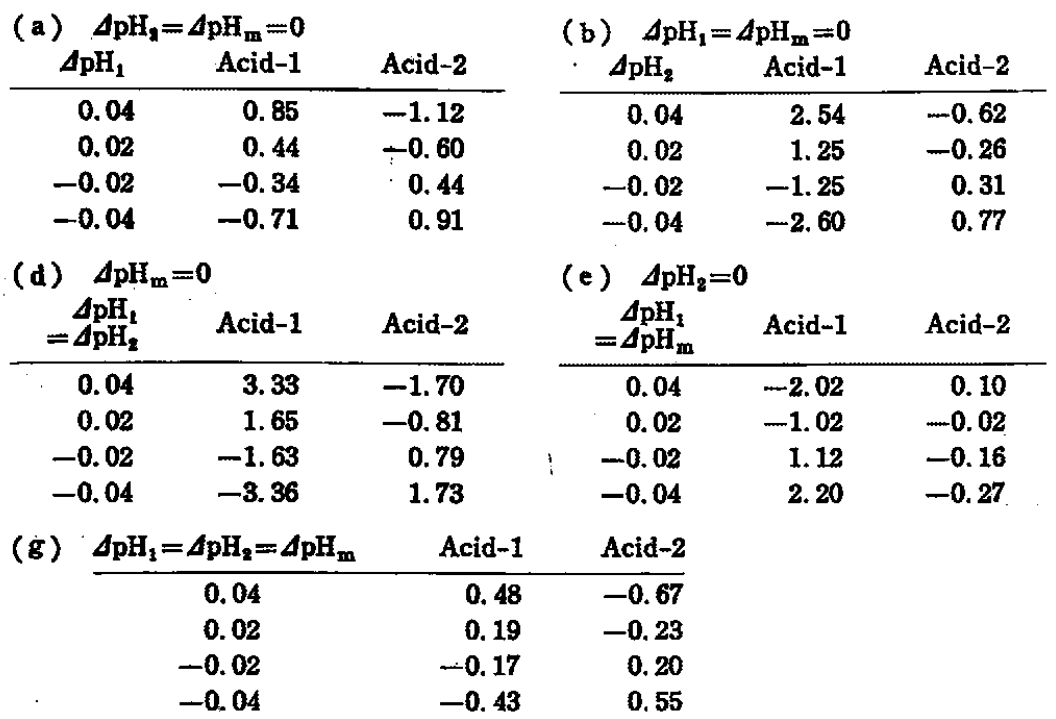

\begin{tabular}{|c|c|c|}
\hline \multicolumn{3}{|c|}{ c) $\Delta \mathrm{pH}_{1}=\Delta \mathrm{pH}_{2}=0$} \\
\hline$\Delta \mathrm{pH}_{\mathrm{m}}$ & Acid-1 & Acid-2 \\
\hline 0.04 & -2.80 & 0.94 \\
\hline 0.02 & -1.41 & 0.52 \\
\hline-0.02 & 1.51 & -0.66 \\
\hline-0.04 & 2.98 & -1.26 \\
\hline
\end{tabular}

( f) $\Delta \mathrm{pH}_{\mathrm{i}}=0$

\begin{tabular}{crr}
$\begin{array}{c}\Delta \mathrm{pH}_{2} \\
=\Delta \mathrm{pH}_{\mathrm{m}}\end{array}$ & \multicolumn{1}{c}{ Acid-1 } & \multicolumn{1}{c}{ Acid-2 } \\
\hline 0.04 & -0.29 & 0.38 \\
0.02 & -0.20 & 0.32 \\
-0.02 & 0.23 & -0.30 \\
-0.04 & 0.36 & -0.43
\end{tabular}

(2) $10^{-8} \mathrm{~mol} / \mathrm{l}$ acid-1 $+5 \times 10^{-3} \mathrm{~mol} / \mathrm{l}$ acid-2

\begin{tabular}{|c|c|c|c|c|c|}
\hline \multicolumn{3}{|c|}{ (a) $\quad \Delta \mathrm{pH}_{2}=\Delta \mathrm{pH}_{\mathrm{m}}=0$} & \multicolumn{2}{|c|}{ (b) $\quad \Delta \mathrm{pH}_{1}=\Delta \mathrm{pH}_{\mathrm{m}}=0$} & \multirow[b]{2}{*}{ Acid-2 } \\
\hline$\Delta \mathrm{pH}_{1}$ & Acid-1 & Acid-2 & $\Delta \mathrm{pH}_{2}$ & Acid-1 & \\
\hline 0.04 & 0.89 & -0.24 & 0.04 & 12.55 & -0.59 \\
\hline 0.02 & 0.48 & -0.13 & 0.02 & 6.13 & -0.23 \\
\hline-0.02 & -0.30 & 0.07 & -0.02 & -6.37 & 0.34 \\
\hline-0.04 & -0.67 & 0.17 & -0.04 & -13.15 & 0.80 \\
\hline
\end{tabular}

(c) $\Delta \mathrm{pH}_{1}=\Delta \mathrm{pH}_{2}=0$

\begin{tabular}{rrr}
\multicolumn{1}{c}{$\Delta \mathrm{pH}_{\mathrm{m}}$} & \multicolumn{1}{c}{ Acid-1 } & \multicolumn{1}{c}{ Acid-2 } \\
\hline 0.04 & -10.85 & 0.11 \\
0.02 & -5.52 & 0.10 \\
-0.02 & 5.90 & -0.23 \\
-0.04 & 11.88 & -0.51
\end{tabular}

(3) $5 \times 10^{-8} \mathrm{~mol} / \mathrm{l}$ acid-1 $+10^{-8} \mathrm{~mol} / \mathrm{l}$ acid-2

\begin{tabular}{|c|c|c|c|c|c|c|c|c|}
\hline \multicolumn{2}{|c|}{ a) $\Delta \mathrm{pH}_{\mathrm{q}}=\Delta \mathrm{pH}_{\mathrm{m}}=0$} & \multirow[b]{2}{*}{ Acid-2 } & \multicolumn{3}{|c|}{ (b) $\quad \Delta \mathrm{pH}_{1}=\Delta \mathrm{pH}_{\mathrm{m}}=0$} & \multicolumn{3}{|c|}{ (c) $\Delta \mathrm{pH}_{1}=\Delta \mathrm{pH}_{2}=0$} \\
\hline $4 \mathrm{pH}_{1}$ & Acid-1 & & $\Delta \mathrm{pH}_{2}$ & Acid-1 & Acid-2 & $\Delta \mathrm{pH}_{\mathrm{m}}$ & Acid-1 & Acid-2 \\
\hline 0.04 & 0.82 & -5.36 & 0.04 & 0.51 & -0.59 & 0.04 & -0.83 & 2.81 \\
\hline 0.02 & 0.41 & -2.75 & 0.02 & 0.26 & -0.23 & 0.02 & -0.42 & $1: 49$ \\
\hline-0.02 & -0.37 & 2.44 & -0.02 & -0.24 & 0.34 & -0.02 & 0.46 & -1.66 \\
\hline-0.04 & -0.74 & 4.81 & -0.04 & -0.51 & 0.81 & -0.04 & 0.87 & -3.01 \\
\hline
\end{tabular}

a) The sample volume is $100 \mathrm{~m} l$. Reference solutions are $10^{-3} \mathrm{~mol} / l$ acid-1 and $10^{-8} \mathrm{~mol} / l$ acid-2. $\Delta \mathrm{pH}_{1}, \Delta \mathrm{pH}_{2}$, and $\Delta \mathrm{pH}_{\mathrm{m}}$ are constant systematic errors in $\mathrm{pH}$ values on the titration curves of reference solutions of acid-1 and acid-2 and on the titration curve of the mixture respectively.

酸 1 または酸 2 の基準液比ついての pH 測定誤盖をそれぞれ $\Delta \mathrm{pH}_{1}, \Delta \mathrm{pH}_{2}$ で、陚料混合物についてのそれを $\Delta \mathrm{pH}_{\mathrm{m}}$ で表わし た。また，計算の都合上， $\mathrm{pH}$ 測定與差は $\mathrm{pH}$ 滴定曲線上の各点 にホいて同し大きさで現かれる，すなわち一定の系統諰差が現わ れるるのとした。流定曲線は(2)（3）式から部算した（後で述へ るようk，水素イオン活量係数を 0.832 とした)。また， $\mathrm{pH}=$

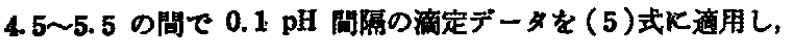
最小二乗法によって棓算した。

各種陚料注度について， $\Delta \mathrm{pH}$ の值をいろいろ仮定したときの 計算結果を表 1 に要約する。これらの計算において，(5)式のブ ロ、トはいずれるは注線となった。また，とくに試料(1)につ いては $\Delta \mathrm{pH}_{1}, \Delta \mathrm{pH}_{2}, \Delta \mathrm{pH}_{\mathrm{m}}$ のいろいろな組み合わせ飞ついても 検㘧しだ。

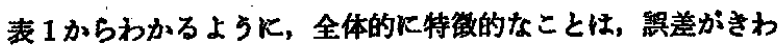
めて小さい捗合を除いて一般同じ $\Delta \mathrm{pH}$ 值について酸 1 と酸 2 の譔羞がたがい、正負逆方向になるといらことである。この傾向
は後で述べように実険的にも認められた。

つぎK， $\Delta \mathrm{pH}_{1}, \Delta \mathrm{pH}_{2}, \Delta \mathrm{pH}_{\mathrm{m}}$ がそれぞれ単独に現われる场合に いてみると（表 $1 の(a) ，(b) ，(c)$ 參照), 正の $\mathrm{pH}$ 测定错差 に対して $\Delta \mathrm{pH}_{1}$ と $\Delta \mathrm{pH}_{2}$ はより強い方の酸 1 亿正愦差を，また 上り弱い方の酸 2 に负罱差を生ずるが，他方 $\Delta \mathrm{pH}_{\mathrm{m}}$ は上記と正 負逆方向の淘差を生ずることがわかる。しかる、これらの関俰は

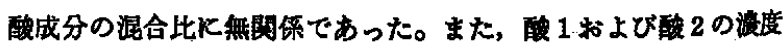

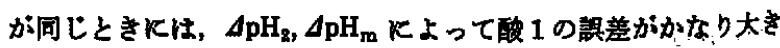

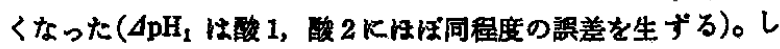
かし, 酸 2 の瀑度が小さいときには， $\Delta \mathrm{pH}_{1}, \Delta \mathrm{pH}_{\mathrm{m}}$ によって酸 2 の错差がきわめて大きくなり，他方，酸 1 の漫度が小さいときに は $\Delta \mathrm{pH}_{2}, \Delta \mathrm{pH}_{\mathrm{m}}$ Kよって酸 1 の俱差がきわめて大きくなった。 したがって，いずれにしてる $\Delta \mathrm{pH}_{\mathrm{m}}$ は可及的に小さくする必要 があり，また隻度が大きい方の酸成分の基楛滴定曲線をより正碓 に求めなければならないことになる。

最後飞， $\Delta \mathrm{pH}_{1}, \Delta \mathrm{pH}_{2}, \Delta \mathrm{pH}_{\mathrm{m}}$ がいろいろな組み合わせで同時飞 
現われる場合についてみると，試料（1)についての結果から（非 $1 の(\mathrm{~d}) \sim(\mathrm{g})$ 参照)，士0.15\% 以内の定量譟差で加成性が成立 ナることが認められた。すなかち、 $\Delta \mathrm{pH}_{1}, \Delta \mathrm{pH}_{2}, \Delta \mathrm{pH}_{\mathrm{m}}$ のらち, 二つ以上が同時に現われるときの全虽差は，それぞれの $\Delta \mathrm{pH}$ 值 が当該浑合物について単独で現われるとしたときの非差の総和で 表わされる。たとえば，混合物試料（1）について， $\Delta \mathrm{pH}_{1}=\Delta \mathrm{pH}_{2}$ $=0.02 の$ とさの加成性からの言美の計算值忙, 表 1 の(1)-(a), (1)-(b)の結果加酸 1 について $0.44+1.25=1.69 \%$; 酸 2 に ついて $-0.60+(-0.26)=-0.86 \%$ となり, 1 の (1)-(d) の結果, すなわち $1.65,-0.81 \%$ とはほ一敌する。

また，各種 $\Delta \mathrm{pH}$ 值の大きさ，方向が異なる例として， $\Delta \mathrm{pH}_{1}=$ $-0.02, \Delta \mathrm{pH}_{2}=0.04, \Delta \mathrm{pH}_{\mathrm{m}}=0.04$ のときの酸 1 およひ酸 2 の 蛪美はそれぞれ 一 $0.66 ， 0.87 \%$ であったが，これを加成性から 計算すると酸 1 で $-0.34+2.54+(-2.80)=-0.60 \%$ 。 酸 2 で $0.44+(-0.62)+0.94=0.76 \%$ となり, や恃り两者は注注一致 した。このよろな加成性は, 㵊合物 (2), (3)についてる成立し た。串際問題としては，pH 計の僄定ミスまたはイオン選択性電

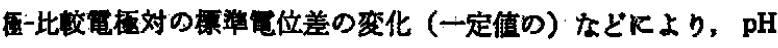

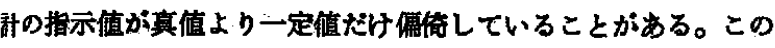
措合には, $\Delta \mathrm{pH}$ 值はすへてて定值だけ同じ方向に現かれるため;

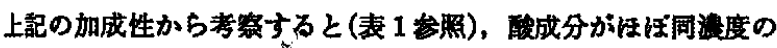
ときは俱差はあまり大きくはならないが，しかし灌度が巽なると き《海度の小さい方の成分の諆差がかかり大きくなるので注意

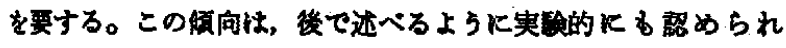
た。

以上の結果は, $\mathrm{pH}$ 俌に一定の系統俱差を仮定したすのである が，実際の場合に多く迹遇するランダム諆盖のときには，上祀の 定量瞋差はかなり小さくなるであろら。

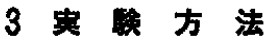

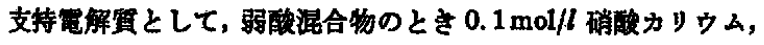

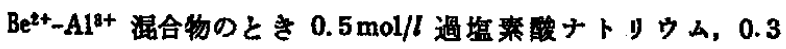
$\mathrm{mol} / l$ 酷酸， $0.06 \mathrm{~mol} / l$ 酶酸ナトリウム ( 度は $0.552 \mathrm{~mol} / l)$ 孝用いた。また，滴定液として，酸・㙁基滴 定で $0.100 \mathrm{~mol} / l$ 水酸化カリウム $(0.1 \mathrm{~mol} / l$ 硝酸カリウムを含 む), フッ化物㴜定では $0.100 \mathrm{~mol} / l$ フッ化テトリウム (0.552

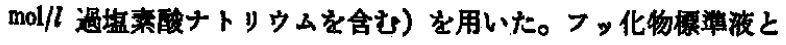
しては，試料液と同じ支持電解筫を含む $10^{-2} お よ ひ ゙ ~ 10^{-\mathbf{a}} \mathrm{mol} / \mathrm{l}$ フッ化ナトリウムを用いた。硝酸カリウムと過塩素酸ナトリウム は、いずれる2 回再結晶した12)。

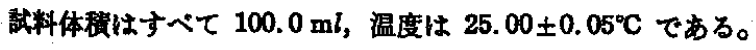
จイクロビュレットの先端に恃テフッンチップをとりつけ，これ によって滴定液の液切れをよくした。

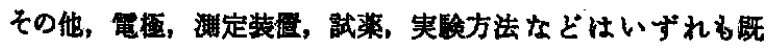
隺と同じである。

\section{4 結果と考萴}

\section{1 嫋酸混合物の分別定量}

$\mathrm{pH}$ 滴定曲線から值接分別定量できない例として, 酢酸（pB= $\left.=4.56^{10}\right)$, 酒石酸 $\left(p \beta_{1}=2.84, p \beta_{2}=6.77^{18)}\right)$, クェン酸 $\left(p \beta_{1}=\right.$

12) 大潼仁志, 電気化学, 44, 151(1976).

13） $0.1 \mathrm{~mol} / l \mathrm{KCl}$ 中Kお゙ける漕度定数 ${ }^{14)}$.
2.87, $\left.p \beta_{2}=7.26, p \beta_{3}=12.90^{19}\right)$ の混合物を用いた（本法の一般 性を示すために, 上部のょうに一塩基酸と多塩基酸の組久合わせ を用いた)。また，[H]の計算のために水素イオン活量俰数 $y_{\mathbf{H}}$ の值が必要であるが（本実験で汢酸性㴭城を訐算化用いるため, $[\mathrm{OH}] \ll[\mathrm{H}]$ としてょい); ここではイオン強度 $0.1 \mathrm{~mol} / \mathrm{l}$ で $\log y_{\mathrm{H}}=-0.08^{15)}$ とした。以下, 基準液としては, すべて $1.04 \times$ $10^{-8} \mathrm{~mol} / l$ 酶酸, $1.00 \times 10^{-8} \mathrm{~mol} / l$ 酒石酸 $.5 .00 \times 10^{-4} \mathrm{~mol} / l$ 多 エン酸を用いまたそれぞれの滴定曲線として 5 回澌定したとき

Table 2 Determination of composition of binary mixtures ${ }^{(a) b)}$

\begin{tabular}{|c|c|c|c|c|}
\hline Components & $\begin{array}{c}c_{\text {Taken }} \times 10^{4} \\
(\mathrm{~mol} / l)\end{array}$ & $\begin{array}{c}c_{\text {round }} \times 10^{4} \\
(\mathrm{~mol} / l)\end{array}$ & $\begin{array}{c}\text { Error } \\
(\%)\end{array}$ & $\begin{array}{l}\text { C. }{ }_{(\%)}{ }^{\circ} \\
\end{array}$ \\
\hline (1) $\left\{\begin{array}{l}A^{d)} \\
T^{d)}\end{array}\right.$ & $\begin{array}{l}10.4 \\
10.0\end{array}$ & $\begin{array}{r}10.3 \\
9.9\end{array}$ & $\begin{array}{l}-0.10 \\
-0.10\end{array}$ & $\begin{array}{l}0.07 \\
0.18\end{array}$ \\
\hline (2) $\left\{\begin{array}{l}\mathrm{A} \\
\mathrm{T}\end{array}\right.$ & $\begin{array}{r}10.4 \\
5.00\end{array}$ & $\begin{array}{r}10.48 \\
4.96_{1}\end{array}$ & $\begin{array}{r}0.77 \\
-0.78\end{array}$ & $\begin{array}{l}0.53 \\
0.43\end{array}$ \\
\hline (3) $\left\{\begin{array}{l}\mathbf{A} \\
\mathbf{T}\end{array}\right.$ & $\begin{array}{l}5.20 \\
10.0\end{array}$ & $\begin{array}{r}\text { 5. } 19_{1} \\
10.0_{0}\end{array}$ & $\begin{array}{r}-0.17 \\
0.00\end{array}$ & $\begin{array}{l}0.45 \\
0.15\end{array}$ \\
\hline (4) $\left\{\begin{array}{l}\mathrm{A} \\
\mathrm{T}\end{array}\right.$ & $\begin{array}{c}10.4 \\
1.00\end{array}$ & $\begin{array}{r}10.4_{0} \\
0.98_{8}\end{array}$ & $\begin{array}{l}0.00 \\
-1.2\end{array}$ & $\begin{array}{l}0.23 \\
0.67\end{array}$ \\
\hline (5) $\left\{\begin{array}{l}A \\
T\end{array}\right.$ & $\begin{array}{l}1.00 \\
10.0\end{array}$ & $\begin{array}{c}0.95_{6} \\
10.0_{5}\end{array}$ & $\begin{array}{r}-4.4 \\
0.50\end{array}$ & $\begin{array}{l}4.9 \\
0.26\end{array}$ \\
\hline (6) $\left\{\begin{array}{l}T \\
C^{d)}\end{array}\right.$ & $\begin{array}{l}\text { 5. } 00 \\
5.00\end{array}$ & $\begin{array}{l}5.05 \\
4.94 \mathrm{i}\end{array}$ & $\begin{array}{r}1.1 \\
-1.2\end{array}$ & $\begin{array}{l}0.35 \\
0.35\end{array}$ \\
\hline (7) $\left\{\begin{array}{l}\mathrm{T} \\
\mathrm{C}\end{array}\right.$ & $\begin{array}{l}5.00 \\
2.00\end{array}$ & $\begin{array}{l}5.03_{1} \\
1.97_{4}\end{array}$ & $\begin{array}{l}0.62 \\
-1.3\end{array}$ & $\begin{array}{l}0.51 \\
0.68\end{array}$ \\
\hline (8) $\left\{\begin{array}{l}\mathrm{T} \\
\mathrm{C}\end{array}\right.$ & $\begin{array}{c}10.0 \\
5.00\end{array}$ & $\begin{array}{r}10.0_{4} \\
\text { 4. } 97_{2}\end{array}$ & $\begin{array}{r}0.40 \\
-0.56\end{array}$ & $\begin{array}{l}0.29 \\
0.58\end{array}$ \\
\hline
\end{tabular}

a) Based on five samples.

b) Reference solutions are $1.04 \times 10^{-3} \mathrm{~mol} / l$ acetic acid, $1.00 \times 10^{-8} \mathrm{~mol} / l$ tartaric acid, and $5.00 \times 10^{-}-\mathrm{mol} / l$ citric acid.

c) Coefficient of variation.

d) $\mathrm{A}=$ Acetic acid, $\mathrm{T}=$ Tartaric acid, $\mathrm{C}=$ Citric acid.

Table 3 Determination of composition of ternary mixtures ${ }^{(a) b)}$

\begin{tabular}{|c|c|c|c|c|}
\hline Components & $c_{(\operatorname{mol} / l)}^{c_{\text {mand }} \times 10^{4}}$ & $c_{\text {Found }} \times 10^{4}$ & $\begin{array}{l}\text { Error } \\
(\%)\end{array}$ & $\begin{array}{l}\left.\text { c. } v_{0}\right)^{\circ} \\
(\%)\end{array}$ \\
\hline (1) $\left\{\begin{array}{l}A^{d)} \\
\mathrm{T}^{d)} \\
\mathrm{C}^{(d)}\end{array}\right.$ & $\begin{array}{c}10.4 \\
10.0 \\
5.00\end{array}$ & $\begin{array}{c}10.4, \\
10.1_{0} \\
4.89_{6}\end{array}$ & $\begin{array}{c}0.87 \\
1.0 \\
-2.1\end{array}$ & $\begin{array}{l}1.2 \\
0.53 \\
2.1\end{array}$ \\
\hline (2) $\left\{\begin{array}{l}A \\
\mathbf{T} \\
\mathrm{C}\end{array}\right.$ & $\begin{array}{c}5.20 \\
10.0 \\
5.00\end{array}$ & $\begin{array}{c}5.30_{8} \\
10.1_{8} \\
4.90_{2}\end{array}$ & $\begin{array}{r}2.1 \\
1.3 \\
-2.0\end{array}$ & $\begin{array}{l}2.7 \\
0.53 \\
1.8\end{array}$ \\
\hline (3) $\left\{\begin{array}{l}\mathrm{A} \\
\mathrm{T} \\
\mathrm{C}\end{array}\right.$ & $\begin{array}{c}10.4 \\
5.00 \\
5.00\end{array}$ & $\begin{array}{c}10.28 \\
4.99 \\
5.04\end{array}$ & $\begin{array}{r}-1.4 \\
-0.08 \\
0.98\end{array}$ & $\begin{array}{l}1.2 \\
0.73 \\
1.9\end{array}$ \\
\hline (4) $\left\{\begin{array}{l}\mathrm{A} \\
\mathrm{T} \\
\mathrm{C}\end{array}\right.$ & $\begin{array}{l}20.8 \\
10.0 \\
1.00\end{array}$ & $\begin{array}{c}20.9_{0} \\
10.0 \\
0.99\end{array}$ & $\begin{array}{r}0.48 \\
0.20 \\
-0.10\end{array}$ & $\begin{array}{l}0.56 \\
0.53 \\
4.8\end{array}$ \\
\hline (5) $\left\{\begin{array}{l}\mathrm{A} \\
\mathrm{T} \\
\mathrm{C}\end{array}\right.$ & $\begin{array}{c}10.4 \\
5.00 \\
0.98\end{array}$ & $\begin{array}{l}10.4_{8} \\
5.08_{8} \\
0.91_{2}\end{array}$ & $\begin{array}{l}0.29 \\
1.7 \\
-6.9\end{array}$ & $\begin{array}{l}1.5 \\
1.4 \\
8.0\end{array}$ \\
\hline (6) $\left\{\begin{array}{l}\mathrm{A} \\
\mathrm{T} \\
\mathrm{C}\end{array}\right.$ & $\begin{array}{c}10.4 \\
1.00 \\
1.00\end{array}$ & $\begin{array}{l}10.3_{1} \\
0.93_{p} \\
1.08_{5}\end{array}$ & $\begin{array}{c}-0.87 \\
-6.1 \\
8.5\end{array}$ & $\begin{array}{l}0.80 \\
4.3 \\
6.1\end{array}$ \\
\hline
\end{tabular}

a) Based on five samples.

b) Reference solutions are $1.04 \times 10^{-\mathrm{a}} \mathrm{mol} / \mathrm{l}$ acetic acid, $1.00 \times 10^{-3} \mathrm{~mol} / \mathrm{l}$ tartaric acid, and $5.00 \times 10^{-4} \mathrm{~mol} / \mathrm{l}$ citric acid.

c) Coefficient of variation.

d) $A=$ Acetic acid, $\mathrm{T}=$ Tartaric acid, $\mathrm{C}=$ Citric acid.

14) 松下 究，弘中搏三，日化，1975，1252.

15) F. Ingman; E. Still; Talanta, 13, 1431(1966). 
Table 4 Determination of composition of mixtures of aluminium and berylliuma)b

\begin{tabular}{|c|c|c|c|c|}
\hline Components & $\begin{array}{c}c_{\text {Taken }} \times 10^{4} \\
(\operatorname{mol} / l) \\
\end{array}$ & $\begin{array}{c}c_{\text {Found }} \times 10^{4} \\
(\mathrm{~mol} / l)\end{array}$ & $\begin{array}{c}\text { Error } \\
(\%)\end{array}$ & $\begin{array}{l}\left.\text { C. } v_{\text {. }}{ }^{c}\right) \\
(\%)\end{array}$ \\
\hline (1) $\left\{\begin{array}{l}\mathrm{Be} \\
\mathrm{Al}\end{array}\right.$ & $\begin{array}{l}5.00 \\
10.0\end{array}$ & $\begin{array}{l}5.07 \% \\
9.91_{8}\end{array}$ & $\begin{array}{l}1.4 \\
-0.82\end{array}$ & $\begin{array}{l}0.42 \\
0.25\end{array}$ \\
\hline (2) $\left\{\begin{array}{l}\mathrm{Be} \\
\mathrm{Al}\end{array}\right.$ & $\begin{array}{c}10.0 \\
5.00\end{array}$ & $\begin{array}{l}10.0_{1} \\
4.95_{1}\end{array}$ & $\begin{array}{r}0.10 \\
-0.98\end{array}$ & $\begin{array}{l}0.45 \\
0.27\end{array}$ \\
\hline (3) $\left\{\begin{array}{l}\mathrm{Be} \\
\mathrm{Al}\end{array}\right.$ & $\begin{array}{l}5.00 \\
5.00\end{array}$ & $\begin{array}{l}5.05_{2} \\
4.97_{8}\end{array}$ & $\begin{array}{c}1.0 \\
-0.54\end{array}$ & $\begin{array}{l}0.55 \\
0.37\end{array}$ \\
\hline (4) $\left\{\begin{array}{l}\mathrm{Be} \\
\mathrm{Al}\end{array}\right.$ & $\begin{array}{l}5.00 \\
1.00\end{array}$ & $\begin{array}{l}5.13_{1} \\
0.85_{6}\end{array}$ & -14 & $\begin{array}{l}0.62 \\
1.4\end{array}$ \\
\hline (5) $\left\{\begin{array}{l}\mathrm{Be} \\
\mathrm{Al}\end{array}\right.$ & $\begin{array}{l}1.00 \\
5.00\end{array}$ & $\begin{array}{l}1.09_{5} \\
4.92_{7}\end{array}$ & $\begin{array}{r}9.5 \\
-1.5\end{array}$ & $\begin{array}{l}1.2 \\
0.40\end{array}$ \\
\hline
\end{tabular}

a) Based on five samples.

b) Reference solutions are $1.00 \times 10^{-3} \mathrm{~mol} / \mathrm{l} \mathrm{Be} \mathrm{Be}^{2+}$ and $1.00 \times 10^{-8} \mathrm{~mol} / \mathrm{l} \mathrm{A1^{3+ }}$.

c) Coefficient of variation.

の平均曲線を用いた。

2 成分混合物の分別定量例を表 2 K示す（試料は 5 個)。これ は, $\mathrm{pH}=4.6 \sim 5.4$ の間で $0.2 \mathrm{pH}$ 間隔の滴定データを(5)式に 䧟用して計算したるのである。表 2 からかかるよらK，No. 5 の 低漶度の方の成分を除いていずれす愦差は $1.5 \%$ 以下，変動係数

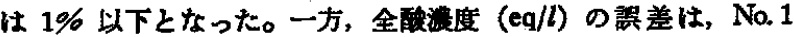
〜8 kついてそれぞれ $-0.10,0.00 ，-0.04 ，-0.16,0.24$, $-0.24 ，-0.13,0.00 \%$ むあり，また变陲係数は $0.10 ， 0.15$, $0.10,0.11,0.19,0.06,0.10,0.09 \%$ でった。この結果と 表 2 の結果をみると，各成分についての誤差，変動係数がある程

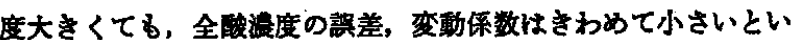
える。

3 成分系混合物の分別定量例を表 3 亿示士(武料は 5 個)。これ は, $\mathrm{pH}=4.6 \sim 5.4$ の間で $0.1 \mathrm{pH}$ 間隔の滴定データを(4)式に 咅用して計算したるのである。表 3 からかかるように，各成分の

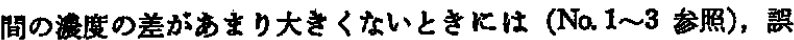

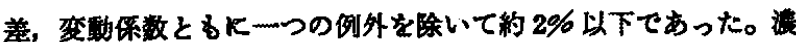
度が大きく異なるとをKは，No.5，6のよ5に瀑度の小さい方の 成分の琵盖が大きくなることるあり，また No.4のように大きく ならないこともあった。しかし，いずれの㧹合も泿度の小さい方
の成分の变動伱数はかなり大きくなった。一方，全酸灌度 (eq/l)

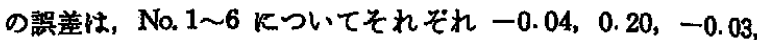
$0.32 ， 0.00,0.26 \%$ であり，また变動保数は $0.18 ， 0.15 ， 0.22$, $0.12,0.20,0.32 \%$ であった。したがって，この場合る各成分

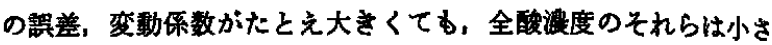
く，2成分系の瀻合とほ注同程度であった。

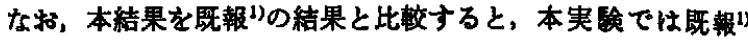
の実臥より濃度を 1/2〜1/10 К小さくしている点を加味すると， 既報の揚合とほぼ同程度の結果が得られるとみてよいであろら。

\section{2 陽イオン混合物の分別定专}

錯形成滴定曲線から直接分别定量できない侧として， Be-Al 混 合物のフッ化物滴定を用いた。以下，基政液としては，すべて， $1.00 \times 10^{-3} \mathrm{~mol} / l \mathrm{Be}^{2+}$ または $\mathrm{Al}^{3+}$ を用いまたそれぞれの商 定曲線として 5 回測定したときの平均曲線を用いた。

分则定量例を㤗 4 亿示す。これは， $\mathrm{pF}=3.2 \sim 4.2$ の間で 0.2 $\mathrm{pF}$ 間隔の滴定データを(5)式に咅用して計算したすのでめる。 表 4 かららかかるようK, $\mathrm{Be}^{2+}, \mathrm{Al}^{8+}$ の洗度がとるK $5 \times 10^{-4} \mathrm{~mol} / \mathrm{l}$

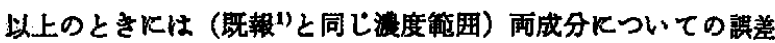
は $1.5 \%$ 以下，交動係数は $0.6 \%$ 以下であり，既報りとほば同 程度の結果が得られた。しかし、No.4，5のように一方の成分 の灌度が $10^{-4} \mathrm{~mol} / \mathrm{l}$ の低湿度になると，その成分の俱差はきわ めて大きくなった。

$\mathrm{Be}^{2+}$ と $\mathrm{Al}^{8+}$ の全濃度の俱盖は，No.1〜5 Kついてそれそれ -0.08，-0.27，0.25，-0.21，0.37\% であり，またその変㲜 係数は $0.11 ， 0.13,0.18,0.25,0.29 \%$ でった。したがって,

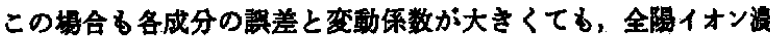
度のそれらはかなり小さくなることがわかる。

以上，本法恃従来の方法2) -8)似くらへ，多成分混合物の分别定 量飞一般的に道用でき，平衡定数の值を必要としない特徽を有す る。また，本法は既報》の方法にくらべ計算に若干手間がかかる が，他方各成分について一つの基渒滴定曲線を作製しておけけばよ く(既報)では各成分について多数の検量線を作慗する必要があ る)，それだけ実鈳操作が简略化される利点がある。

\section{Titrimetric Determination of Weak Acids or Cations in Their \\ Mixture by Solving Simultaneous Equations Using lonic \\ Concentrations as Variables}

Norihisa IsHrkawa and Hiroshi Matsushita

\section{Department of Industrial Chemistry, Chubu Institute of} Technology ; Matsumoto-cho, Kasugai-shi 487 Japan

Linear simultaneous equations based on exact material- and charge-balance relationships were proposed in order to determine the composition of mixtures of weak acids or cations by using the results obtained by a potentiometric titration.

The procedure is as follows; Titration curves for the reference solutions of components of the mixture (known concentrations) and the sample mixture were obtained at a constant ionic strength by using an ion-selective electrode. Volumes of titrant required to reach a constant ionic concentration (i.e., constant electrode potential) were read off respectively on titration curves of the mixture and its components. Then, the composition of the mixture could be determined by solving simultaneous equations involving the measured ionic concentrations and the volumes of titrant as variables (see Eqs. (4) and (11)).

The present method has an advantage that equilibrium constants are not necessary for the calculation of the concentration. 